\title{
KEMAMPUAN PEMECAHAN MASALAH MAHASISWA PADA POKOK BAHASAN ANUITAS DAN ASURANSI
}

\author{
Ai Tusi Fatimah \\ Program Studi Pendidikan Matematika, FKIP, Universitas Galuh, \\ Jln. R.E. Martadinatan No 150 Ciamis, 46251, Ciamis \\ e-mail: tusi.fatimah@gmail.com
}

\begin{abstract}
Abstrak. Kemampuan pemecahan masalah berperan penting dalam penyelesaian masalah anuitas dan asuransi. Kemampuan mahasiswa terhadap pemecahan masalah dapat dilihat dari kemampuan menyelesaikan setiap fase pemecahan masalah yang dikemukakan oleh Polya. Tujuan penelitian ini adalah untuk mengetahui tingkat kemapuan pemecahan masalah mahasiswa pada pokok bahasan anuitas dan asuransi. Responden dalam penelitian ini adalah mahasiswa program S-1 Pendidikan Matematika Universitas Galuh Ciamis yang mengikuti mata kuliah Aktuaria tahun akademik 2015/2016 sebanyak 102 orang. Data yang digunakan dalam penelitian ini adalah hasil tes berbentuk uraian yang terdiri dari empat soal. Hasil tes diukur secara parsial melalui empat fase, yaitu memahami masalah, merancang rencana, melaksanakan rencana dan memeriksa kembali. Skor maksimal yang diperoleh mahasiswa untuk masing-masing fase adalah $46.6 \%, 51.2 \%$, $22.6 \%$ dan $20.6 \%$ yang merupakan rerata dari empat soal yang diujikan.
\end{abstract}

Kata Kunci: Kemampuan pemecahan masalah, anuitas, asuransi.

\section{PENDAHULUAN}

Memecahkan masalah adalah keterampilan kognitif yang kompleks yang menjadi salah satu ciri kegiatan manusia yang paling cerdas (Chi \& Glasser, 1980). Keterampilan kognitif tersebut harus didasarkan pada sebuah metode yang benar untuk mendapatkan solusi. Metode pemecahan masalah yang populer, pertama kali dikemukakan oleh Polya pada tahun 1945 dalam bukunya How to Solve it.

Polya (1988) menyatakan empat fase pada proses pemecahan masalah untuk menemukan solusi, yaitu fase memahami masalah, merancang rencana, melaksanakan rencana dan memeriksa kembali. Keempat fase tersebut dapat digunakan untuk mengukur kemampuan pemecahan masalah secara parsial. Fase memahami masalah berhubungan dengan kemampuan pemahaman matematis, dengan indikator dapat menterjemahkan simbol dan kalimat matematis. Fase merancang rencana erat kaitannya dengan kemampuan penalaran dan pemilihan prosedur sehingga diperoleh pemodelan yang tepat. Fase melaksanakan rencana berhubungan dengan kemampuan komputasi untuk mendapatkan hasil yang benar. Sedangkan fase memeriksa kembali untuk melihat kebenaran seluruh proses.

Terdapat dua kategori pada proses pemecahan masalah dalam fase merancang rencana dilihat dari ada tidaknya algoritma atau prosedur untuk menyelesaikan masalah. Proses pemecahan masalah yang sudah ada algoritma atau prosedur dipandu oleh aturan-aturan yang terdapat pada algoritma atau prosedur tersebut. Sedangkan proses pemecahan masalah yang tidak terdapat algoritma atau prosedurnya, proses pemecahan masalah bergantung pada pengetahuan dan keterampilan orang yang menyelesaikan masalah tersebut.

Masalah yang dipecahkan dapat merupakan masalah rutin atau tidak rutin. Pemecahan masalah dari masalah tidak rutin merupakan keterampilan yang penting, tetapi pemecahan dari masalah yang rutin juga merupakan keterampilan yang diperlukan dan tidak dapat diabaikan. Pemecahan masalah rutin tidak hanya 
menerapkan keterampilan prosedural, tetapi juga diperlukan pemilihan prosedur yang tepat untuk mendapatkan solusi yang benar (Laterell, 2000).

Pemilihan prosedur yang tepat dapat terkendala dengan banyaknya formula atau rumus yang berkaitan dengan suatu masalah. Misalkan pada pokok bahasan tertentu formula untuk memecahkan masalah dapat digunakan secara mandiri, tetapi banyak juga masalah yang bisa dipecahkan dengan menggunakan formulaformula dari beberapa pokok bahasan. Hal ini terjadi seperti pada materi aktuaria.

Aktuaria adalah sebuah disiplin ilmu, cabang dari matematika yang dapat diterapkan pada sistem analisis resiko terutama pada perusahaan asuransi dan bagian keuangan perusahaan. Aktuaria mengaplikasikan ilmu keuangan, teori statistik, teori peluang dan pemrograman komputer untuk menyelesaikan persoalanpersoalan yang menyangkut analisis kejadian masa depan yang berdampak pada segi keuangan, khususnya yang berhubungan dengan besar pembayaran pada masa depan dan kapan pembayaran dilakukan pada waktu yang tidak pasti.

Anuitas dan asuransi merupakan pokok-pokok bahasan yang terdapat pada mata kuliah Aktuaria. Menurut Kitab Undang-undang Hukum Dagang (KUHD) pasal 246 disebutkan bahwa " Asuransi atau pertanggungan adalah perjanjian, di mana penanggung mengikat diri terhadap tertanggung dengan memperoleh premi, untuk memberikan kepadanya ganti rugi karena suatu kehilangan, kerusakan, atau tidak mendapat keuntungan yang diharapkan, yang mungkin akan dapat diderita karena suatu peristiwa yang tidak pasti". Sedangkan anuitas adalah suatu deretan pembayaran yang jumlahnya sama, yang diterima atau dibayarkan pada tiap awal/akhir periode dengan waktu yang sama untuk jumlah waktu tertentu. Masalah yang muncul dari keduanya adalah menghitung besarnya premi dan penerimaan atau santunan. Perhitungan premi dan penerimaan dari anuitas dan asuransi dapat berdiri sendiri atau keduanya saling berhubungan.

Premi adalah sejumlah uang yang harus dibayarkan sebagai kewajiban dari tertanggung atas keikutsertaannya di asuransi. Besarnya premi atas keikutsertaan asuransi yang harus dibayarkan telah ditetapkan oleh perusahaan asuransi dengan memperhatikan keadaan-keadaan dari tertanggung. Premi yang dibayarkan dapat berupa premi tunggal, premi tahunan atau premi yang dibayar beberapa kali setahun.

Contoh penerimaan dari keikutsertaan asuransi jiwa adalah santunan. Santunan adalah dana yang diperoleh oleh ahli waris sebagai pengganti kerugian (akibat kecelakaan, kematian dan sebagainya) dengan ketentuan yang disepakati. Sedangkan contoh penerimaan dari anuitas adalah dana pensiun. Dana pensiun dapat diberikan sekaligus atau berkala (bulanan, tahunan, beberapa kali setahun).

Terdapat banyak jenis anuitas dan asuransi yang dipelajari sehingga terdapat banyak pula formula untuk perhitungan besar premi dan penerimaan. Hal ini cukup menyulitkan mahasiswa dalam menyelesaikan masalah-masalah yang diberikan. Berdasarkan uraian di atas, maka perumusan masalah dalam penelitian ini adalah bagaimanakah kemampuan pemecahan masalah mahasiswa pada pokok bahasan anuitas dan asuransi?

\section{METODE PENELITIAN}

Penelitian ini merupakan penelitian deskriptif. Data yang digunakan dalam penelitian ini adalah hasil tes berbentuk uraian. Responden dalam penelitian ini adalah mahasiswa program S-1 Pendidikan Matematika Universitas Galuh Ciamis yang mengikuti mata kuliah Aktuaria tahun akademik 2015/2016 sebanyak 102 orang. 


\section{HASIL DAN PEMBAHASAN}

Hasil tes yang dilakukan terhadap 102 respoden diukur secara parsial melalui empat fase, yaitu memahami masalah, merancang rencana, melaksanakan rencana dan memeriksa kembali. Setiap fase diberi skor dengan pedoman penskoran merujuk pada Smarter Balanced Mathematics General Rubric yang dimodifikasi. Tabel berikut menyajikan pedoman penskoran yang dilakukan untuk mengetahui kemampuan pemecahan masalah pada bahasan anuitas dan asuransi.

Tabel 1. Pedoman Penskoran Pemecahan Masalah

\begin{tabular}{|c|c|c|c|c|}
\hline SKOR & $\begin{array}{l}\text { MEMAHAMI } \\
\text { MASALAH }\end{array}$ & $\begin{array}{c}\text { MERANCANG } \\
\text { RENCANA }\end{array}$ & $\begin{array}{l}\text { MELAKSANAKAN } \\
\text { RENCANA }\end{array}$ & $\begin{array}{l}\text { MEMERIKSA } \\
\text { KEMBALI }\end{array}$ \\
\hline 3 & & $\begin{array}{l}\text { Mahasiswa } \\
\text { membuat rencana } \\
\text { secara lengkap } \\
\text { sesuai dengan } \\
\text { prosedur } \\
\text { (penalaran dan } \\
\text { pemodelan) } \\
\text { matematika. }\end{array}$ & $\begin{array}{l}\text { Mahasiswa } \\
\text { Melakukan rencana } \\
\text { dengan prosedur } \\
\text { yang benar dan } \\
\text { mendapatkan hasil } \\
\text { yang benar. }\end{array}$ & \\
\hline 2 & $\begin{array}{l}\text { Mahasiswa } \\
\text { memahami } \\
\text { masalah secara } \\
\text { lengkap. }\end{array}$ & $\begin{array}{l}\text { Mahasiswa } \\
\text { membuat rencana } \\
\text { tetapi belum } \\
\text { lengkap sesuai } \\
\text { dengan prosedur } \\
\text { (penalaran dan } \\
\text { pemodelan) } \\
\text { matematika. }\end{array}$ & $\begin{array}{l}\text { Mahasiswa } \\
\text { melakukan rencana } \\
\text { dengan prosedur } \\
\text { yang benar tetapi } \\
\text { tidak mendapatkan } \\
\text { hasil komputasi } \\
\text { yang benar. }\end{array}$ & $\begin{array}{l}\text { Mahasiswa } \\
\text { melakukan } \\
\text { pemeriksaan } \\
\text { untuk melihat } \\
\text { kebenaran proses }\end{array}$ \\
\hline 1 & $\begin{array}{l}\text { Mahasiswa } \\
\text { memahami } \\
\text { masalah secara } \\
\text { parsial isi soal }\end{array}$ & $\begin{array}{l}\text { Mahasiswa } \\
\text { membuat rencana } \\
\text { secara parsial } \\
\text { yang mengarah } \\
\text { pada prosedur, } \\
\text { tetapi terdapat } \\
\text { formula yang } \\
\text { salah. } \\
\text { atau } \\
\text { Mahasiswa } \\
\text { memahami ide-ide } \\
\text { masalah tetapi } \\
\text { pengetahuannya } \\
\text { tidak cukup } \\
\text { sehingga } \\
\text { membuat prosedur } \\
\text { yang salah. }\end{array}$ & $\begin{array}{l}\text { Mahasiswa } \\
\text { melakukan sebagian } \\
\text { rencana yang } \\
\text { mengarah pada } \\
\text { prosedur, salah } \\
\text { menentukan simbol } \\
\text { komutasi sehingga } \\
\text { tidak mendapatkan } \\
\text { hasil yang benar. }\end{array}$ & $\begin{array}{l}\text { Mahasiswa } \\
\text { melakukan } \\
\text { pemeriksaan } \\
\text { tetapi tidak tuntas. }\end{array}$ \\
\hline 0 & $\begin{array}{l}\text { Mahasiswa tidak } \\
\text { Memahami } \\
\text { masalah }\end{array}$ & $\begin{array}{l}\text { Mahasiswa salah } \\
\text { dalam merancang } \\
\text { rencana. } \\
\text { Mahasiswa tidak } \\
\text { membuat rencana. }\end{array}$ & $\begin{array}{l}\text { Mahasiswa tidak } \\
\text { melaksanakan } \\
\text { rencana. }\end{array}$ & $\begin{array}{l}\text { Mahasiswa tidak } \\
\text { melakukan } \\
\text { pemeriksaan. }\end{array}$ \\
\hline
\end{tabular}


Pedoman penskoran digunakan untuk menilai seberapa jauh kemampuan mahasiswa dalam menyelesaikan keempat fase pemecahan masalah. Dari masingmasing soal yang diberikan, dianalisa untuk membandingkan tingkat kemampuannya. Oleh sebab itu kita dapat melihat kelebihan dan kekurangan mahasiswa dalam melakukan proses pemecahan masalah pada suatu fase tertentu.

Empat soal yang diujikan kepada mahasiswa bervariasi. Pertanyaan yang ditujukan adalah untuk mencari besar premi, santunan atau penerimaan. Prosedur pemecahan masalah untuk menyelesaikan masalah-masalah pada soal tersebut dapat menggunakan prosedur anuitas, asuransi atau anuitas dan asuransi. Soal pertama adalah pemecahan masalah anuitas, soal kedua dan ketiga merupakan soal pemecahan masalah yang menggunakan konsep anuitas dan asuransi, sedangkan soal keempat menggunakan konsep asuransi untuk memecahkan masalah.

Setiap soal diberi skor berdasarkan pedoman penskoran pada Tabel 1. Berikut disajikan tabel untuk menggambarkan kemampuan pemecahan masalah dalam bentuk persen dari setiap skor yang diperoleh.

Tabel 2. Persentase Skor

Fase Memahami masalah

\begin{tabular}{ccccc}
\hline \multirow{2}{*}{ SKOR } & \multicolumn{4}{c}{ SOAL NOMOR } \\
\cline { 2 - 5 } & 1 & 2 & 3 & 4 \\
\hline 0 & 2.9 & 3.9 & 9.8 & 3.9 \\
\hline 1 & 41.2 & 79.4 & 52.0 & 20.6 \\
\hline 2 & 55.9 & 16.7 & 38.2 & 75.5 \\
\hline
\end{tabular}

Hasil skor fase memahami masalah menunjukkan bahwa soal nomor empat memperoleh persentase yang paling besar, yakni $75.5 \%$ mahasiswa mampu memahami masalah secara lengkap. Sedangkan pada soal nomor tiga dan dua, mahasiswa yang memperoleh skor ideal hanya di bawah $40 \%$. Hal ini terjadi dikarenakan mahasiswa kurang memahami simbol-simbol anuitas dan asuransi dari kalimat matematis yang terdapat pada soal.
Tabel 3. Persentase Skor

Fase Merancang Rencana

\begin{tabular}{ccccc}
\hline \multirow{2}{*}{ SKOR } & \multicolumn{4}{c}{ SOAL NOMOR } \\
\cline { 2 - 5 } & 1 & 2 & 3 & 4 \\
\hline 0 & 3.9 & 27.5 & 14.7 & 2.9 \\
\hline 1 & 25.5 & 42.2 & 36.3 & 11.8 \\
\hline 2 & 2.9 & 12.7 & 8.8 & 5.9 \\
\hline 3 & 67.6 & 17.6 & 40.2 & 79.4 \\
\hline
\end{tabular}

Hasil skor fase membuat rencana menunjukkan bahwa mahasiswa yang dapat membuat rencana secara lengkap sesuai dengan prosedur (penalaran dan pemodelan) matematika yang paling kecil persentasenya terdapat pada nomor dua, yakni sebanyak $17.6 \%$. Hal ini terjadi dikarenakan mahasiswa melakukan beberapa kesalahan penalaran dalam pemilihan prosedur. Kemampuan penalaran mahasiswa terhadap penjelasan fakta, sifatsifat dan hubungan antara anuitas dan asuransi masih kurang. Mahasiswa melakukan kesalahan dalam menentukan persamaan penyelesaian dan penentuan formula, sehingga diperoleh pemodelan yang tidak tepat.

Tabel 4. Persentase Skor

Fase Melaksanakan Rencana

\begin{tabular}{ccccc}
\hline \multirow{2}{*}{ SKOR } & \multicolumn{4}{c}{ SOAL NOMOR } \\
\cline { 2 - 5 } & 1 & 2 & 3 & 4 \\
\hline 0 & 2.0 & 14.7 & 5.9 & 3.9 \\
\hline 1 & 48.0 & 83.3 & 64.7 & 29.4 \\
\hline 2 & 11.8 & 2.0 & 29.4 & 14.7 \\
\hline 3 & 38.2 & 0 & 0 & 52.0 \\
\hline \multicolumn{2}{c}{ Mahasiswa } & harus & \multicolumn{2}{c}{ mempunyai }
\end{tabular}

keterampilan komputasi dan ketelitian membaca tabel simbol komutasi dalam fase melaksanakan rencana ini. Tidak ada mahasiswa yang melakukan rencana dengan prosedur yang benar dan mendapatkan hasil yang benar dalam mengerjakan soal nomor dua dan tiga. Dua persen mahasiswa melakukan rencana dengan prosedur yang benar tetapi tidak mendapatkan hasil komputasi yang benar dikarenakan kurang terampil dalam proses komputasi. 
Tabel 5. Persentase Hasil

Fase Memeriksa Kembali

\begin{tabular}{ccccc}
\hline \multirow{2}{*}{ SKOR } & \multicolumn{4}{c}{ SOAL NOMOR } \\
\cline { 2 - 5 } & 1 & 2 & 3 & 4 \\
\hline 0 & 32.4 & 53.9 & 50.0 & 22.5 \\
\hline 1 & 37.3 & 46.1 & 50.0 & 25.5 \\
\hline 2 & 30.4 & 0 & 0 & 52.0 \\
\hline
\end{tabular}

Berdasarkan tabel di atas, persentase mahasiswa yang tidak melakukan proses pemeriksaan untuk melihat kebenaran proses cukup besar. Hal ini berhubungan dengan fase-fase sebelumnya. Ketidaktuntasan melakukan rencana menyebabkan pemeriksaan kembali proses hanya dilakukan sebagian.

Secara keseluruhan, Hasil dari empat soal yang diberikan, rata-rata perolehan skor maksimal untuk kemampuan memahami masalah adalah $46,6 \%$, rata-rata perolehan skor maksimal untuk kemampuan merancang rencana adalah 51,2\%, rata-rata perolehan skor maksimal untuk kemampuan melaksanakan rencana adalah $22,6 \%$ dan rata-rata perolehan skor maksimal untuk kemampuan memeriksa kembali adalah $20,6 \%$. Hal ini menunjukkan adanya masalah kemampuan pemecahan masalah pada soal yang menggunakan konsep anuitas dan asuransi secara bersama-sama. Sedangkan kemampuan pemecahan masalah untuk soal-soal yang menggunakan konsep anuitas dan asuransi secara terpisah dapat dikatakan cukup dengan persentase skor maksimal yang diperoleh terlihat pada tabel. Oleh sebab itu, supaya mahasiswa dapat menyelesaikan masalah dengan benar, harus melakukan langkah-langkah sebagai berikut: 1) mahasiswa harus memahami masalah dari kalimat matematika sehingga dapat membedakan simbol-simbol anuitas dan asuransi. Simbol-simbol tersebut berhubungan dengan jenis premi, jenis anuitas, jenis asuransi, dan jenis penerimaan. Jenis premi berdasarkan waktu pembayaran adalah premi tunggal, tahunan, beberapa kali setahun), 2) mahasiswa melakukan penalaran dengan menjelaskan fakta, sifat, dan hubungan anuitas, asuransi, premi dan penerimaan. Hasil dari penalaran akan diperoleh model dan prosedur yang tepat. 3) mahasiswa harus terampil melakukan komputasi dengan prosedur yang benar. 4) mahasiswa harus memeriksa kembali semua proses secara lengkap.

\section{SIMPULAN}

Kemampuan pemecahan masalah berperan penting dalam penyelesaian masalah anuitas dan asuransi. Kemampuan mahasiswa terhadap pemecahan masalah dapat dilihat dari kemampuan menyelesaikan setiap fase pemecahan masalah. Keempat fase pemecahan masalah tersebut terlihat parsial tetapi semuanya saling berkaitan. Kemampuan pemecahan masalah juga berkaitan dengan kemampuan matematis yang lain diataranya kemampuan pemahaman, penalaran dan komputasi. Kemampuan pemecahan masalah ini diharapkan dapat ditumbuhkembangkan kepada mahasiswa melalui pengajuan masalah yang bervariasi sehingga memungkinkan mahaiswa untuk mengkonstruksi model-model anuitas dan asuransi.

\section{DAFTAR PUSTAKA}

Bower, N.L., et al. (1997). Actuarial Mathematics. USA: The Society of Actuaries.

Chi, M. T. H. Problem Solving Ability. [Online]. Diakses dari http://www.public.asu.edu/ $\sim$ mtchi/papers/ ChiGlaser10.pdf.

Kitab Undang-Undang Hukum Dagang (Wetboek van Koophandel voor Indonesia).S. 1847-23. [Online]. Diakses dari http://hukum.unsrat.ac.id/uu/kuhd.h $\underline{\mathrm{tm}}$.

Laterell, C. M. (t.t). What Is Problemsolving Ability?. [Online]. Diakses 
dari

http://www.lamath.org/journal/Vol 1/What_IS_P_S_Ability.pdf.

Sugiman, Kusumah, Y. S. \& Sabandar, Z.

Pemecahan Masalah Matematik dalam Matematika Realistik. [Online]. Diakses dari http://staff.uny.ac.id/sites/default/fil es/ 131930135/2009a_PM_dalam_PM R.pdf.

Smarter Balanced Assesment Consoitium. ( t. t). Smarter Balanced Mathematics General Rubric.[Online]. Diakses dari http://www.ode.state.or.us/wma/tea chlearn/testing/ scoring/guides/2011-

12 /mathpsscoringguide eng.pdf.

Polya, George. (1988). How to Solve It: A New Aspect of Mathematical Method (Second ed.). Princeton , N.J.: Princeton Science Library Printing. 